\title{
Reading Trauma Narratives: Insidious Trauma in the Story of Rachel, Leah, Bilhah and Zilpah (Genesis 29-30) and Margaret Atwood's The Handmaid's Tale
}

\section{Juliana Claassens (Stellenbosch University, South Africa)}

\begin{abstract}
This article investigates the notion of insidious trauma as a helpful means of interpreting the story of Rachel, Leah, Bilhah and Zilpah as told in Genesis 29-30 that has found its way into the haunting trauma narrative of Margaret Atwood's The Handmaid's Tale.

In the first instance, this article outlines the category of insidious trauma as it is situated in terms of the broader field of trauma hermeneutics, as well as the way in which it relates to the related disciplines of feminist and womanist biblical interpretation. This article will then continue to show how insidious trauma features in two very different, though intrinsically connected trauma narratives, i.e., the world imagined by Atwood in The Handmaid's Tale, and the biblical narrative regarding the four women through whose reproductive efforts the house of Israel had been built that served as the inspiration for Atwood's novel.
\end{abstract}

This article argues that these trauma narratives, on the one hand, reflect the ongoing effects of systemic violation in terms of gender, race and class, but also how, embedded in these narratives there are signs of resistance that serve as the basis of survival of the self and also of others.

KEYWORDS: The Handmaid's Tale; Rachel; Leah; Bilhah; Zilpah; Trauma Narratives; Reproductive Loss; Insiduous Trauma

\section{A INTRODUCTION}

In the increasingly popular field of trauma hermeneutics that utilizes insights from trauma theory in order to read old texts in new ways, ${ }^{1}$ the intersection of

* Submitted: 17/11/2019; peer-reviewed: 14/02/2020; accepted: 10/03/2020. L. Juliana Claassens, "Reading Trauma Narratives: Insidious Trauma in the Story of Rachel, Leah, Bilhah and Zilpah (Genesis 29-30) and Margaret Atwood's The Handmaid's Tale," Old Testament Essays 33 no. 1 (2020): 10 - 31. DOI: https://doi.org/ 10.17159/2312-3621/2020/v33n1a3.

1 In recent years, the notion of trauma and insights from trauma theory have become quite important for the study of biblical texts, both in the Hebrew Bible and in the New Testament. In this regard, David Janzen offers an excellent overview of the pertinent developments in trauma theory that is significant for the study of biblical texts, The 
trauma and gender has been not as prominent as one would expect. It may be that trauma in the past had been associated with major cataclysmic events that on a large scale threaten to undo the world of individuals as well as communities. Or that trauma theory initially was focused specifically on the experiences and needs of white men. ${ }^{2}$ However, feminist clinical psychologists Maria Root and Laura Brown have long since challenged this definition of what is understood under "real" trauma, and hence developed the category of insidious trauma to be more inclusive of experiences pertaining to gender, race, class and sexual orientation. ${ }^{3}$ With reference to insidious trauma, the intersection of gender, race and trauma becomes an important trajectory to attend to the daily minor, and not so minor, acts of violation that in particular affect women and minorities. The category of insidious trauma thus acknowledges that female bodies, and quite often also black and brown female bodies, are bodies in pain.

In terms of trauma hermeneutics, this article proposes that the recognition of insidious trauma offers a productive means for reading trauma narratives, both ancient and modern, which document the ongoing, often hidden pain experienced by women and other individuals and groups who find themselves at the margins of what a society considers to be normative. Reading trauma narratives serves as a powerful tool in uncovering the reality of insidious trauma that reflects the ongoing effects of systemic violation in terms of gender, race and class. However, trauma narratives also serve as a testament to resilience and survival as evident in the often subtle signs of resistance that also may be found amidst such portrayals of insidious trauma.

Violent Gift: Trauma's Subversion of the Deuteronomistic History's Narrative (New York: Bloomsbury T\&T Clark, 2012), 26-44. Moreover, for a helpful overview on the development of trauma hermeneutics of the Bible, cf. the helpful article by David G. Garber, "Trauma and Biblical Studies," Currents in Biblical Studies 14/1 (2015): 2444. Cf. also two recent collections of essays that reflect the scope and impact of trauma hermeneutics and the Bible, Elizabeth Boase and Christopher G. Frechette (eds.), Bible through the Lens of Trauma (Semeia Studies 86; Atlanta: SBL Press, 2016) and EveMarie Becker, Jan Dochhorn, and Else Holt (eds.), Trauma and Traumatization in Individual and Collective Dimensions: Insights from Biblical Studies and Beyond (Göttingen: Vandenhoeck \& Ruprecht, 2014).

2 Maria P. P. Root, "Reconstructing the Impact of Trauma on Personality," in Personality and Psychopathology: Feminist Reappraisals (ed. Laura S. Brown and Mary Ballou; New York: The Guilford Press, 1992), 229-265 (here 230).

3 Root, "Reconstructing," 231, 258. Cf. also Laura Brown, "Not Outside the Range: One Feminist Perspective on Psychic Trauma," in Trauma: Explorations in Memory (ed. Cathy Caruth; Baltimore: John Hopkins University Press, 1995), 100-112 (here 110-111). 
As part of a larger project, ${ }^{4}$ this article brings into conversation the contemporary trauma narrative of Margaret Atwood's novel, The Handmaid's Tale, and the biblical narrative of Leah and Rachel, who gave their handmaids, Bilhah and Zilpah, to Jacob in order to bolster their own struggles with fertility (Gen 29-30). Atwood's striking portrayal of insidious trauma in The Handmaid's Tale finds its roots in the biblical story that can be described as the original "handmaid's tales." 5

We will see in this article how the stories of the four mothers of the twelve tribes of Israel as narrated in Genesis 29-30 are steeped in what can be described as insidious trauma. This is quite evident in the deep-seated, ongoing pain experienced by the two sisters, Rachel and Leah, who fell victim to society's expectation of women's destiny that is categorically linked to their ability to bring a child into the world. However, we will also see how Rachel's and Leah's actions adversely impacted on the lives of their handmaids, Bilhah and Zilpah, who became pawns in the so-called baby wars.

Moreover, as evident in the epigraph to the The Handmaid's Tale, which was first published in 1985 and has recently quite dramatically been catapulted into people's consciousness, it is exactly the story of Rachel, Leah, Bilhah and Zilpah that inspired Atwood to use this particular biblical narrative as the governing trope for her novel. It seems as if the novel's haunting vision of a dystopian world in which women's fertility had been adversely affected by an environmental crisis, resulting in a number of young women forcefully given as handmaids to their affluent owners with the sole purpose of bringing a child into the world, is striking a chord with a new generation of readers. This may be due

4 This article forms part of my forthcoming monograph, Writing and Reading to Survive: Biblical and Contemporary Trauma Narratives in Conversation, which is scheduled for publication end of 2020 with Sheffield Phoenix Press. In addition to offering a theoretical framework for considering aspects of the text production and reception of biblical and contemporary trauma narratives, this monograph offers a number of examples of such creative engagements between biblical stories of especially women's secret or hidden traumas and a number of contemporary trauma novels.

5 According to Amy Kalmanofsky, this "battle for babies" points to "an independent desire" on the part of the two sisters, which, in the words of the title of her book, makes them "dangerous sisters" indeed, Dangerous Sisters of the Hebrew Bible (Minneapolis, MN: Fortress, 2014), 27. 
in no small measure to the Trumpian era politics and policies, ${ }^{6}$ in addition to the success of the award winning Hulu series based on this novel. ${ }^{7}$

This article will, in the first instance, outline the category of insidious trauma as it is situated in terms of the broader field of trauma hermeneutics, as well as the way in which it relates to the related disciplines of feminist and womanist biblical interpretation. This article will then continue to show how insidious trauma features in two very different, though intrinsically connected trauma narratives, i.e., the world imagined by Atwood in The Handmaid's Tale, and the biblical narrative regarding the four women through whose reproductive efforts the house of Israel was built and that served as the inspiration for Atwood's novel. The fact that the biblical story of Leah and Rachel is read at the time of the Ceremony (when the handmaid, in the presence of the entire household, is given to the Commander) points to the interconnectedness of these two narratives. ${ }^{8}$ And in the final section, this article considers the significance of reading these two trauma narratives in conjunction in terms of their respective portrayal of insidious trauma as well as resistance. It will be suggested that by entering the world conjured up by these trauma narratives, and by joining the characters in their often difficult journey of coming to terms with the trauma they had experienced, readers actually may gain some insight into their own experiences of insidious trauma. For as Martha Nussbaum has compellingly argued, by reading literature, and specifically also the genre of tragedy, readers

6 The Handmaid's Tale seems to be resonating with people's experience of ongoing dangers posed to women in the current political climate in the United States, but also around the world. For instance, in an op-ed piece in the Huffington Post during the early days of the current president of United States, Kayla Chadwick invokes the example of The Handmaid's Tale, writing how readers/viewers of the series draw strength from the defiance by the protagonist in The Handmaid's Tale in the context of the "existential terror" experienced by many in the Trump presidency, "Don't Let the Bastards Grind You Down: Nolite te bastardes carborundorum, bitches," Huffington Post 29 August 2017. Available at https://www. huffingtonpost.com/entry/dont-let-the-bastards-grind-youdown us 59095e17e4b05279d4edc109 Accessed 4 March 2018.

7 Cf. e.g. the recent wins of the Hulu show at the 2017 Emmy Awards and 2018 Golden Globes, as well as the opening at the Emmy Awards that saw a procession of women in red handmaid's gowns and white head coverings singing and dancing with host Stephen Colbert that also made a strong political statement. "Stephen Colbert Performs Musical Opening with 'Handmaid' Dancers | Emmys 2017," available at https://www.hollywoodreporter.com/video/stephen-colbert-performs-musical-opening-handm aid-dancers-emmys-2017-1040244 Accessed 22 February, 2018.

8 Shirley Neuman, "Just a Backlash': Margaret Atwood, Feminism, and The Handmaid's Tale," University of Toronto Quarterly 75/3 (2006): 857-868 (here 857). 
are able to try out different responses to life's ethical dilemmas in the safe space of a narrative. ${ }^{9}$

\section{B DEFINING INSIDIOUS TRAUMA}

Insidious trauma can be described as the ongoing, traumatizing experiences that especially affect women and minorities in terms of systemic racism, sexism, homophobia, as well as poverty. According to Root, "insidious trauma is usually associated with the social status of an individual being devalued because a characteristic intrinsic to their identity is different from what is valued by those in power." 10 Such acts where an individual or group is constantly degraded, or one could say dehumanized, due to one's gender, class, race or sexual orientation are "insidious" in nature because they are "cumulative," hence occurring throughout the individual's lifetime, sometimes even starting from a very early age. Moreover, directed toward an individual or an entire group of people, acts of micro and/or macro-aggression may recur in such a manner that relationships of power and control are both established and sustained. ${ }^{11}$

Perhaps precisely because of the continuing nature of these injurious events, the effects of insidious trauma are severe, adversely impacting the emotional and psychological wellbeing of the individual, including the ability to trust, to exert control over one's environment, to have a healthy sense of one's own worth, and to recognize one's ability to serve as an autonomous agent. ${ }^{12}$ Adding to this suffering is the fact that the traumatizing effects of these experiences of ongoing violation based on gender, race and class have been negated and/or underplayed for a long time. According to Laurie Vickroy, the social and cultural environment is often shaped in such a way that many, even the survivors themselves, may fail to recognize these experiences as traumatic in nature. ${ }^{13}$

In this regard, a feminist perspective on trauma is critical as it offers an important step in recognizing the reality of racism, sexism, homophobia and inequality in creating environments where individuals and groups are suffering real harm. Taking seriously the "individual's subjective experience of an event or series of events," a feminist perspective on trauma helps to "depathologize normal responses to horrible experiences that transcend daily and developmental

9 Cf. Martha Nussbaum's work on the role of literature and art in helping to cultivate compassion in e.g. Political Emotions: Why Love Matters for Justice (Cambridge, MA: Harvard University Press, 2013), 178-179.

10 Root, "Reconstructing," 240.

11 Root, "Reconstructing the Impact," 230, 240. Cf. also Laurie Vickroy, "Voices of Survivors in Contemporary Fiction," in Contemporary Approaches to Trauma Theory (ed. Michelle Balaev; New York: Palgrave MacMillan, 2014), 130-151 (here 132).

12 Vickroy, "Voices of Survivors," 132-133.

13 Vickroy, "Voices of Survivors," 130. 
hassles and stresses." 14 As Root rightly reminds us, when it comes to trauma, "everyone has a breaking point." 15 In addition, a feminist understanding of trauma recognizes the impact of a social environment to contribute further to the suffering that victims experience by, for instance, blaming the victims of interpersonal violence and/or questioning the veracity of their feelings or reports. ${ }^{16}$ And finally, a feminist understanding of trauma considers the role of the embodied self, understanding that one of the most serious "wounds of trauma is the crushing of the human spirit," which according to Root "may indeed be the hardest wound to heal."17

Finally, exploring the intersection of trauma, gender, race and class which involves acknowledging and naming the reality of insidious trauma in literature and in life has distinct ethical implications. Brown goes so far as to describe its potential impact as "revolutionary" in terms of its ability to "challenge the status quo" and to "participate in the process of social change." 18 In this regard, the parallels with feminist biblical interpretation are clear. Feminist biblical interpreters in the past four decades have sought to interrogate what classically has been described by Phyllis Trible as "Texts of Terror," i.e. the manifold stories of rape and sexual violence found throughout biblical literature. ${ }^{19}$ But beyond these overt instances of gender-based violence, one also finds how patriarchy in the Hebrew Bible in itself can be said to be a form of structural violence that greatly impacts women's subjectivity, their ability to make independent decisions or express their own thoughts and feelings, and especially to control their bodies. ${ }^{20}$

$\begin{array}{ll}14 & \text { Root, "Reconstructing," } 237 . \\ 15 & \text { Ibid. } \\ 16 & \text { Root, "Reconstructing," } 236 . \\ 17 & \text { Root, "Reconstructing," } 238 . \\ 18 & \text { Brown, "Not Outside the Range," 110-111. } \\ 19 & \text { Phyllis Trible, Texts of Terror: Literary-Feminist Readings of Biblical Narratives }\end{array}$ (Philadelphia: Fortress, 1984). Cf. also Harold C. Washington, "Violence and the Construction of Gender in the Hebrew Bible: A New Historicist Approach," BibInt 5 (1997): 324-363. Particularly in the prophetic traditions, sexual violence is used as a metaphor for the devastation experienced by the people and their city. Cf. e.g. Deryn Guest, "Hiding Behind the Naked Women in Lamentations: A Recriminative Response," BibInt 7/4 (1999): 413-448; Brad E. Kelle, "Wartime Rhetoric: Prophetic Metaphorization of Cities as Female," in Writing and Reading War: Rhetoric, Gender and Ethics in Biblical and Modern Contexts (ed. Brad E. Kelle and Frank R. Ames; Atlanta, GA: Society of Biblical Literature, 2008), 95-112.

20 Nancy Bowen, "Women, Violence, and the Bible," In Engaging the Bible in a Gendered World: An Introduction to Feminist Biblical Interpretation in Honor of Katharine Doob Sakenfeld (ed. Linda Day and Carolyn Pressler; Louisville, KY: Westminster John Knox, 2006), 186-199 (here 190). 
In addition, womanist biblical interpreters offer a crucial corrective when it comes to exploring the intersection of gender and trauma in their insistence on reading in more than one vein. As Mitzi Smith writes, "woman biblical scholars cannot... analyse texts, contexts, and readers through the framework of gender and ignore issues of race or through the lens of race and overlook concerns of class." ${ }^{21}$ In this regard, a helpful illustration underscoring the importance of this intersection of gender, race, class and insidious trauma is the notion of "the crooked room," used by womanist scholar Melissa Harris-Penny in order to capture the ongoing trauma African American women experience in a world where white is considered normative and hence superior. Signifying a psychological experiment that compels subjects to sit on crooked chairs in a crooked room, it is shown that to constantly be in a situation where one is devalued and dehumanized due to one's gender, race, sexual orientation or socioeconomic circumstances has the effect of leading individuals to embrace this crooked view of the world. ${ }^{22}$ The crooked room experiment compellingly demonstrates the long-term psychological harm caused by systemic racism, sexism, homophobia and inequality, which rightly could be described in terms of the category of insidious trauma.

In the rest of this article, it will be shown how two trauma narratives, one ancient and one modern, connected by their focus on the control of female sexuality and reproduction, can be said to reflect the notion of insidious trauma as outlined above.

\section{INSIDIOUS TRAUMA IN THE HANDMAID'S TALE}

The Handmaid's Tale offers a chilling rendition of the notion of insidious trauma as evident in the premise of the preoccupation with procreation as the true destiny of women. The instrumentalization of women based on ethnicity and social class serves as the impetus for the novel's portrayal of a new hierarchical society in which women are delegated to the categories of handmaids whose sole function it is to conceive a child for their owners; Martha's to serve; and prostitutes, as in ages past, to pleasure, so fulfilling men's desire for illicit, hidden sexual pleasures. In addition to these categories, there also are the Aunts who forcefully

21 Mitzi Smith, "This Little Light of Mine: The Womanist Biblical Scholar as Prophetess, Iconoclast, and Activist," in I Found God in Me: A Womanist Biblical Hermeneutics Reader (ed. Mitzi J. Smith; Eugene, OR: Cascade Books, 2015), 109-130 (here 111). Cf. also the recent collection of essays offering some innovative biblical interpretations by group of Womanist biblical scholars edited by Gay L. Byron and Vanessa Lovelace, Womanist Interpretations of the Bible: Expanding the Discourse (Atlanta, GA: SBL, 2016).

22 Melissa Harris-Penny, Sister Citizen: Shame, Stereotypes, and Black Women in America (New Haven, CT: Yale University Press, 2011), 35. Cf. also Shelly Rambo, Resurrecting Wounds: Living in the Afterlife of Trauma (Waco, TX: Baylor University Press, 2017), 85-86. 
instill a new class system and teach its undergirding values, as well as the Commanders' Wives, who live a life of affluence and privilege. And not fitting into any of these designated roles are the women of the underclass who are banished to the colonies where these undesirables are said to engage in toxic cleanup work that caused them not to survive long in the hazardous conditions.

In The Handmaid's Tale, the individual stories of women's suffering as told through the perspective of one particular handmaid are connected to larger systemic and environmental concerns. This is quite evident as the widespread infertility is attributed to an environmental crisis that saw pollutants and pesticides inadvertently affecting the birth rates of the population, causing more and more women to be infertile. ${ }^{23}$

By drawing on the biblical story of Rachel, Leah, Bilhah and Zilpah, Atwood depicts an alarming effect in The Handmaid's Tale a world in which all the hard-won freedoms of women have been suddenly and irrevocably reversed, which align with the description of insidious trauma outlined above. ${ }^{24}$ By piecing together "the handmaid's tale" from tapes that were discovered much later, the reader learns the following about the handmaid Offred as she is called by her owners (Of-Fred, the name of the Commander's house to which she has been assigned). Offred, whose real name is June, ${ }^{25}$ previously was in an educated, privileged position, only to be reduced to her ability to bear children for her barren commander' wife, Serena by the new societal order. Through June's often fragmented recollections, the reader learns something of the ongoing anguish she experiences in terms of the situation in which she finds herself, told via traumatic memories in terms of flashbacks to her life before. We learn of the day in which her, as well as all other women's, bank accounts were frozen, in addition to all women being banned from working outside the home. Eventually, June is

23 B. C. Indu, "Flowers of Survival: An Ecofeminist Reading of Margaret Atwood's The Handmaid's Tale," International Journal of Humanities and Social Science Invention 2/4 (2013):7-9. Available at http://www.ijhssi.org/papers/v2(4)/version2/B24070 9.pdf. Accessed March 3, 2018

${ }^{24}$ Neuman writes that in the 1980s when The Handmaid's Tale first appeared, Atwood, like many other feminists of the time, was "keenly aware of the fragility of the newly acquired rights and equalities of women," "Just a Backlash," 858. Yet she also acknowledges that it was no utopia before. According to Neuman, Atwood has her main character remember the time before as a world filled with sexual violence and child abuse, where it was not safe for women to walk alone, and where women all too often were raped, abducted and even killed, p 866.

25 Cf. though Margaret Atwood's interesting response to the connection between Offred and June drawn by readers: "That was not my original thought but it fits, so readers are welcome to it if they wish," "Margaret Atwood on What "The Handmaid's Tale' Means in the Age of Trump," New York Times, 10 March, 2017. Available online at https://www.nytimes.com/2017/03/10/books/review/margaret-atwood-handmaidstale-age-of-trump.html. Accessed September 4, 2019. 
violently separated from her partner and child and forced, together with other selected, presumably fertile handmaids, to take up their true calling of bringing children into the world on behalf of their owners.

Throughout the novel, we witness a vivid portrayal of insidious trauma as evident in the daily disdain June for instance experiences as the Commander's wife Serena Joy, acts coldly and distantly if not with contempt at June's presence in her house. What's more, the novel contains harrowing descriptions of the prohibition of reading; the loss of education, religion, and anything that may potentially critique or distract from the new societal order; and the almost daily public execution of intellectuals, clergy and dissidents. These expressions of insidious trauma clearly demonstrate that this new world order is rooted in fear and force, which all the more contribute to the situation of severe and ongoing suffering that June is experiencing. ${ }^{26}$

There are clear links to the biblical narrative from which Atwood has drawn her inspiration. So this story in ritualized fashion is invoked at length during the monthly Ceremony which viscerally and quite publicly re-enacts the giving of the handmaid. Moreover, it is telling that the chosen handmaids also are being "educated" in the Leah and Rachel Education Centre by a number of elder Aunts who forcefully initiate a new (or rather old) regime. ${ }^{27}$ In this dramatic remaking of the world, the biblical narrative of Rachel, Leah and their two handmaids Zilpah and Bilhah is invoked in both ritual and education in order to engineer a new society where gender and class norms are firmly in place and women are compelled to adhere to what is considered to be their true calling. Within this new order, women's right to choose, to employment, to be educated, to have agency, to freedom of movement - all the freedoms and rights that June's mother's generation had fought for are eradicated. ${ }^{28}$ The Handmaid's Tale thus

\footnotetext{
26 Neuman, "Just a Backlash," 864-865.

27 Neuman calls this novel a "fictional realization of the backlash against women's rights," - in the early eighties when the book was written, but disturbingly so also today, "Just a Backlash," 858. Cf. also the fascinating thesis by Alanna A. Callaway regarding the way in which women in this novel are depicted to oppress other women as in the example of the Aunts who are educating the handmaids to accept their place in the new hierarchical class system, and Serena Joy, a former celebrity singer, who now is shown to proclaim the values of the new normal. "Women Disunited: Margaret Atwood's The Handmaid's Tale as a critique of feminism," (2008). Master's Theses. 3505. 50-55. https://doi.org/10.3138/utq.75.3.857.

28 Neuman offers a fascinating analysis of the world which forms the backdrop for Atwood's novel which includes a clear diminishing of women's rights during the Reagan years in the United States, “Just a Backlash," 859-860. The early eighties is also a time when "Ayatollah Khomeini forced women out of Iranian universities, out of their jobs, and back into their burqas and their homes. Iranian prison refugees reported torture including the use of electric prods and frayed steel cables in beatings, and such a report by one woman found its way into Atwood's file," (p. 859).
} 
reflects a chilling exposé of the feminist backlash, as the novel imagines a devastating return of the patriarchal regime. Margaret Atwood's novel serves as a haunting reminder not to be complacent. For in this novel, the patriarchal system reasserted itself with a vengeance.

However, despite this very grim portrayal of insidious trauma that affects women from all walks of life, there also are a number of very interesting traces of resistance that give hope not only to the characters of The Handmaid's Tale but also to its readers who connect in various ways with the plight of the characters. Most significant is the made-up Latin reference, Nolite te bastardes carborundorum ("Don't let the bastards grind you down"), that the main character, Offred (or June as she is called in her previous life), discovers in her room. Written by a previous occupant of the room, these hidden words reflect the reality of suffering and violation another handmaid had experienced in this same space, but also the resolve not to yield to attempts to keep her down.

\section{INSIDIOUS TRAUMA IN THE STORY OF RACHEL, LEAH, BILHAH AND ZILPAH (GENESIS 29-30)}

In the story of the original "handmaids' tales" in Genesis 29-30, one finds a striking portrayal of what has been described in this article as insidious trauma. In the case of Rachel and Leah, a great deal of pain is caused by societal expectations to bring as many children as possible into the world. Throughout the narrative it is evident that their obsession to have children is not only determined by societal norms that value women predominantly for their ability to procreate, but also by their deep desire to gain the attention and affection of Jacob.

In this regard, Leah is shown to suffer greatly as the unwanted and unloved wife of Laban. ${ }^{29}$ The object of her father Laban's scheme to outwit/trick Jacob, which had been part of a much longer battle for control between the two

29 In terms of the overall rhetorical function of this contrast, it is evident that Leah's outward appearance over which she has little control is the reason that she is unwanted and unloved by Jacob her husband. So the two sisters are contrasted in terms of their looks. Rachel in Gen 29:17 is described as very beautiful in form and face [cf. Dennis Olson's translation of "graceful and beautiful" - offering a sharp contrast with Leah who is said to have "weak/feeble" eyes (rakkôt in Hebrew)]. Cf. Mignon R. Jacobs, Gender, Power, and Persuasion: The Genesis Narratives and Contemporary Portraits (Grand Rapids, MI: Baker Academic, 2007), 161; Dennis Olson, "Revenge, Forgiveness, and Sibling Rivalry: A Theological Dialogue Between Scripture and Science" Ex Auditu 28 (2012): 94-119 (here 114). Even though several interpreters have tried to mitigate this description by saying that this reference could also be understood as "soft" or "kind" eyes, Genesis 29-30 channels society's fascination with outward appearances in explaining Laban's preference for Rachel instead of Leah. 
men, Leah unwittingly finds herself as the wife of Jacob. ${ }^{30}$ One could well imagine the resentment and scorn she conceivably experienced from her new husband who now is compelled to work for another seven years in order to win the hand of his beloved Rachel in marriage. The effect of this rejection, in addition to the arranged marriage in which Leah finds herself, is evident in the names she gives to the first three sons born to her that all testify to the pain and humiliation she experiences by not being the subject of love and affection on the part of her husband. For instance, Leah gives the following explanations for the names of her first three sons-Reuben: "Because the Lord has looked on my affliction; surely now my husband will love me" (Gen 29:32); Simeon: "Because the Lord has heard that I am hated, he has given me this son also" (Gen 29:33); Levi: "Now this time my husband will be joined to me, because I have borne him three sons" (Gen 29:34). On the one hand, this act of naming her three sons according to Joan Ross-Burstall demonstrates close links to the lament tradition, hence offering a window into the deep pain and suffering experienced by Leah. ${ }^{31}$ However, on the other hand, one should not miss how Leah's act of naming of her sons, and especially also the sons of her handmaid Zilpah, constitutes an act of force as her own suffering inadvertently is conferred upon her children.

Further evidence of the deep pain that Leah must have experienced by being unloved by her husband is evident in Gen 29:31 which says that when God heard that Leah was "hated," God opened up her womb. As Wilda Gafney points out, the text does not merely say that Leah was unloved, but rather that she was "hated," thereby evocatively expressing the level of suffering that she is experiencing. ${ }^{32}$ Moreover, after the birth of Judah, her fourth son, it is said that Leah stopped bearing children, which perhaps may suggest that Jacob's indifference to Leah reached a new level in that her infertility could be attributed to the fact that Jacob is no longer sharing her bed, hence relegating Leah to a situation of forced barrenness. From a feminist perspective, this notion of forced barrenness can be said to be further evidence of how the needs of the patriarch utterly dictate the lives of the subservient women, so underscoring the role of patriarchy in creating a situation of insidious trauma.

Also Rachel suffers greatly from her lifelong struggle to become a mother - the effect on Rachel tellingly voiced in her desperate exclamation to Jacob: "Give me children or I will die!" (Gen 30:1). Indeed as Jacobs aptly captures

\footnotetext{
30 Jacobs argues that the fact that neither Rachel nor Leah has any say in their father's choice of marriage partner for them demonstrates the absolute power of Laban as well as the lack of control by women of their situation, Gender, Power, and Persuasion, 162. 31 Joan Ross-Burstall, "Leah and Rachel: A Tale of Two Sisters," Word \& World 14/2 (1994): 162-170 (here 164-167).

32 Wilda C. Gafney, Womanist Midrash: A Reintroduction to the Women of the Torah and the Throne (Louisville, KY: Westminster John Knox, 2017), 64; Jacobs, Gender, Power, and Persuasion, 170.
} 
women's struggle with fertility then (and also now), infertility involves the anguish of "waiting, seeing other women have children, resigned to their infertility and eventually taking matters into their own hands to remedy the situation." ${ }^{33}$ Rachel's suffering is furthermore evident in terms of the deep pain caused by, as a woman struggling with infertility, having to live in a house with other mothers with young children (cf. the examples of Sarah and Hagar and Hannah and Peninah). In this regard, Candida Moss and Joel Baden point out that the name of Rachel's first born son, Joseph, that is said to mean "God has taken away my disgrace" (Gen 30:23), reflects something of the great emotional and psychological anguish associated with the shame a barren woman would have had to endure in a world that valued fertility. ${ }^{34}$

Ironically enough, Rachel in the end will die in childbirth (Gen 35:16-20) - her drive to have children in the end being responsible for her demise, ${ }^{35}$ but also serving as a grim reminder of just how dangerous giving birth in the ancient world was. ${ }^{36}$ The deep level of suffering experienced by Rachel is evident in the name she gives to her son born just before she dies in childbirth - Ben-Amoni, "Son of my Suffering" (Gen 35:16). It is telling that even this act of agency by the dying woman is erased, when Jacob renames the child Benjamin "Son of strength" (literarily "right hand son" in Gen 35:19). ${ }^{37}$ Nevertheless, Rachel's association with suffering returns when somewhere along the way, Rachel becomes a symbol of the suffering people as a whole. ${ }^{38}$ It is significant that this woman's suffering on a personal level with barrenness and the very real fear of suffering and dying in childbirth became the primary means for expressing the

33 Jacobs, Gender, Power, and Persuasion, 167.

34 Candida R Moss and Joel S Baden, Reconceiving Infertility: Biblical Perspectives on Procreation and Childlessness (Princeton, NJ: Princeton University Press, 2017), 39. Cf. the important argument of infertility being more of a social construct where women who cannot have children are made to feel shame/disgrace being viewed as social outcasts. In terms of the social construction of the time, to be barren was considered to be more dead than alive, $\mathrm{p} 35$.

35 Moss and Baden, Reconceiving Infertility, 35.

36 Carol Meyers, Rediscovering Eve: Ancient Israelite Women in Context (Oxford: Oxford University Press, 2013), 99-100.

37 Gafney, Womanist Midrash, 61. Cf. also Kalmanofsky who draws on the work of Esther Fuchs, says that "Rachel hopes to inscribe her suffering in her son's name but instead, her act of agency is overridden by Jacob as he selects a name for his new born son "that conveys strength and optimism instead," Dangerous Sisters, 33.

38 Gafney, Womanist Midrash, 61. Cf. the prophet Jeremiah that invokes Rachel's lament in Jer 31:15 that in turn is quoted in Matt 2:18. Gafney describes Rachel as a "motherless child a long way from home" (cf. the absence of any reference to Rachel and Leah's mother). Moreover, by dying in childbirth, Gafney reminds us that there will be "another generation of motherless children," p 62. Cf. also Ekaterina E Kozlova, Maternal Grief in the Hebrew Bible (Oxford: Oxford University Press, 2017), 169-173. 
nation's ongoing trauma in the context of being threatened with annihilation during and after the Babylonian invasion and exile.

Also the measures that Leah took in order to remedy her situation of being unable for a time to bear children is testimony of the potentially traumatizing effects of infertility on women both then and now. Even after having given birth to four sons already, not only does Leah join Rachel in giving her handmaid as surrogate to Jacob, but Reuben, her firstborn son, also gets involved by finding love potion ("mandrakes"39 in Gen 30:14) for his mother in a desperate effort to win her husband's affection. Leah's statement to her sister, "Is it a small matter that you have taken away my husband?" (Gen 30:15) reveals the deep hurt she has been experiencing all this time in terms of her ongoing battle with her sister for her husband's affection. ${ }^{40}$ In this regard, both Leah and Rachel's suffering can be described in terms of the notion of insidious trauma caused by systemic injustice in this story. As Jacobs rightly observes, the "dynamics of women's relationships" is to be understood as the "by-products of systems implemented by men." ${ }^{41}$ Hence, Rachel deeply suffers for not having children, while Leah is experiencing profound pain for being not only unloved, but also hated, by her husband.

The story of insidious trauma in which Rachel and Leah appear to play a central role extends much further and more deeply. So the story of these two women really should be called the story of Rachel, Leah, Bilhah and Zilpah. The desperate quest for love and fulfilment of societal expectations also affects others when both Leah and Rachel gave their handmaids to Jacob in their quest to provide their husband with male heirs. This act of compelling Bilhah and Zilpah to sleep with Jacob is solely focused on compensating for Rachel's barrenness, and for Leah, to win Jacob's affection. Rachel and Leah's absolute power over their servants is also evident in the way that Rachel and Leah name the children born to Bilhah (Dan and Naphtali in Gen 30:6-8) and to Zilpah (Gad and Asher in Gen 30:10-13), so forever shaping their identity in terms of the owners' needs and desires.

Not many authors recognize or even notice the two handmaids who have no voice nor agency to resist being used for the benefit of their owners' aspirations. An exception would be womanist scholars such as Gafney who asks poignant questions in order to bring into focus Bilhah and Zilpah, who together were responsible for producing a third of Israel's twelve tribes. She calls Zilpah and Bilhah "[p]awns in the war for Jacob's attention and affection," arguing that

\footnotetext{
39 Gafney describes the reference to mandrakes in the text as "love-fruit" which was thought to be "within bounds of legitimate health care," Womanist Midrash, 58. Cf. also Moss and Baden, Reconceiving Infertility, 24.

40 Gafney, Womanist Midrash, 64-65.

41 Jacobs, Gender, Power, and Persuasion, 175.
} 
"through the wombs of Rachel, Leah, Bilhah and Zilpah, Israel's people were birthed by choice and by force... They are casualties of nation building." 42 Also Susanne Scholz rightly defines what happens to Bilhah and Zilpah as sexual violence, as she recognizes the forced sexual relations into which these two, presumably, young women are compelled. ${ }^{43}$ This is even more evident in the reference in Gen 35:22 that Bilhah was raped by Jacob's firstborn son, Reuben. As Gafney thoughtfully remarks: "The pain, anguish, rage and shame that Bilhah must have felt are difficult to imagine. In the text no punishment is meted out to Reuben. No comfort is offered to Bilhah in the text."44

Even though Bilhah and Zilpah are without voice in this biblical text, the extent of their trauma may be imagined in terms of other examples of systemic violation within the biblical text and beyond. For instance, the cries in the wilderness of another slave woman Hagar regarding the abuse and torment she had experienced at the hands of her owner, conceivably offers a window into what Bilhah and Zilpah would have experienced. In this regard, Gafney argues that the sexual subordination of the handmaids Zilpah and Bilhah "evokes abuse of enslaved Africans in US, Caribbean and other places." 45

To focus our attention on Bilhah and Zilpah reminds us that an intersectional understanding of gender is crucial. When contemplating the deeply traumatizing effects of the ongoing suffering of women and minorities due to their assigned gender roles in a patriarchal society, and given also the connotations of slavery cited above, it is essential to consider also the effects of race and class. In this regard, Margaret Aymer writes in her poignant essay on the slave girl Rhoda in Acts 12 about the importance of "reading darkness," and even more so, as womanist scholars have helped us to see, "to read darkness intersectionally. Race and gender and class oppression, taken collectively, cause black women's trauma." 46 Similarly, if one takes seriously the notion of insidious trauma in this biblical text, one may be more mindful of the pain and anguish caused by the double, and in the case of Bilhah and Zilpah, triple levels of

42 Gafney, Womanist Midrash, 70. Gafney asks poignant questions intended to give these two slave women a voice: "Were they born in captivity? Were they spoils of war? How long were they in Laban's service? And what services did they provide to Laban?," p 67.

43 Susanne Scholz, Sacred Witness: Rape in the Hebrew Bible (Minneapolis, MN: Fortress, 2010), 56-57.

44 Gafney, Womanist Midrash, 68.

45 Gafney, Womanist Midrash, 67. Cf. also Delores Williams' discussion of surrogate motherhood that often marked African American Women's experience, Sisters in the Wilderness: The Challenge of Womanist God-Talk (Maryknoll, NY: Orbis, 1993).

46 Margaret Aymer, "Outrageous, Audacious, Courageous, Willful: Reading the Enslaved Girl of Acts 12," in Womanist Interpretations of the Bible: Expanding the Discourse (ed. Gay L. Byron and Vanessa Lovelace; Atlanta, GA: SBL, 2016), 265290 (here 265). 
degradation that may even be more painful in the sense that it is not recognized nor validated.

\section{E RECOLLECTION, RESISTANCE AND RECOVERY}

So, what would the function be of such candid portrayals of insidious trauma in both The Handmaid's Tale and the biblical narrative of Rachel, Leah, Bilhah, and Zilpah that inspired Margaret Atwood's novel? First, to view trauma narratives through the lens of insidious trauma helps us to be cognizant of the ways in which the personal stories of these women inadvertently are linked to broader societal and environmental concerns. In this regard, the conversation with reference to the connection between individual and collective trauma is quite interesting. Trauma narratives form part of the social processes involved in what Jeffrey Alexander describes as "the symbolic construction and framing, of creating stories and characters," in order to construct a collective identity to make sense of "a shared cultural trauma."47

In terms of the world in which Rachel, Leah, Bilhah and Zilpah reside, the story of infertility and the drive to procreate is associated with the general vulnerability of a people that greatly suffered from infant mortality and maternal deaths in childbirth. ${ }^{48}$ However, one also finds how the often desperate quest to have children is focused on securing the survival of a people who found themselves in a situation of great precarity. ${ }^{49}$ One could thus say that the story of Rachel, Leah, Bilhah and Zilpah, which potentially was finalized during or after the time of the exile, can be said to reflect something of the anxiety and anguish of a vulnerable people in the aftermath of war and exile. ${ }^{50}$ In this regard, it is important to continue to reflect on the way in which the micro stories

47 Jeffrey Alexander, Trauma: A Social Theory (Cambridge: Polity Press, 2012), 3. Cf. also Ron Eyerman, "Social Theory and Trauma," Acta Sociologica 56/1 (2013): 4153 (here 43).

48 Laura W. Koepf-Taylor, Give Me Children or I Shall Die: Children and Communal Survival in Biblical Literature (Minneapolis, MN: Fortress, 2013), 98; Meyers, Rediscovering Eve, 98-99.

49 This theme of barrenness and strife that runs through the ancestral traditions hence serves to highlight the ongoing nature and effects of trauma on individuals and the community as a whole that will continue long after. So, the story of the pain experienced by Rachel, Leah, Bilhah and Zilpah started long before their time as prefigured in stories of e.g. Sarah and Rebecca's barrenness, and Sarah's subsequent treatment of her KoepfTaylor handmaid Hagar, Koepf-Taylor, Give Me Children, 48-51.

50 This argues that the preoccupation with (in)fertility is likely an exilic/postexilic concern according to which "communal survival extends beyond familial boundaries to the broader cultural community, most particularly in the context of diaspora," Give Me Children, 126. Cf. also Kalmanofsky's discussion regarding the story of Leah and Rachel encapsulating the foundations of Israel as nation, Dangerous Sisters, 24. 
documenting women's suffering may also represent a much broader narrative that constitutes a story of shared cultural trauma.

These communal narratives are important in the way they may help individuals as well as the community at large to cope with trauma. As Alexander has argued, they may help to "trigger significant repairs in the civil fabric." 51 However, Alexander also warns that these narratives can "instigate new rounds of social suffering." 52 For instance, one may indeed wonder how the relationships between these four women through whom the house of Israel had been built, as well as their descendants after them, may have looked in future. It is likely that the forced surrogacy that marked their story of origin would continue to forge a stratified society in which the injustice of the past would be perpetuated.

Second, trauma narratives that document the seen and unseen suffering of the female protagonists are important because they validate the experiences of those who find themselves in a similar situation of ongoing torment and abuse. Trauma narratives that document insidious trauma may play an important role in acknowledging what Laurie Vickroy describes as the reality of "the devastating isolation and abandonment others inflict on the wounded" as well as "the silencing power of the environment." ${ }^{.53}$ At the same time, reading trauma narratives constitutes a powerful mechanism to help readers make sense of trauma. It is quite helpful to observe the way in which some characters (not all) throughout the course of the narrative are able to gain greater insight into their situation. In this regard, Vickroy writes that Atwood typically portrays "characters as narrators of their own stories, after the fact, where they revisit their process of awakening." 54 "[Atwood's] narrators, often the protagonists... begin to piece together narratives of their lives in relation to their communities. Traumatized characters are offered clues and bits of memories to reassess survival and finally engage in new ways of thinking and being." ${ }^{.55}$

\footnotetext{
$51 \quad$ Alexander, Trauma, 2.

52 Ibid.

53 Ibid. Vickroy argues that even though it is possible to critique "its delusional premises," the reality is that "often only a few characters who are able to break out of the established patterns." This is particularly true in terms of what Maria Root and Laura Brown have argued, i.e. that an essential aspect of insidious trauma is that the "the social or cultural environment [that] may suppress acknowledgement of trauma," "Voices of Survivors," 130.

54 Vickroy, "Voices of Survivors," 130-131.

55 Vickroy, "Voices of Survivors," 131. Cf. also Neuman who proposes that the first step to utopia amidst the dystopia depicted in the novel is to " pay attention' and 'bear witness,' as does Offred when she uses her uncertain freedom to tell her story," "Just a Backlash,", 866.
} 
Thus, in The Handmaid's Tale, a central feature of the narrative is the way in which the narrator, June or Offred as she is now called, after the fact seeks to piece together what happened - fragmented, limited in nature but constituting an attempt to put into words what had happened. Part of her journey of making sense of what she is experiencing is associated with the words Nolite te bastardes carborundorum discovered by Offred written by the previous occupant of the room. Even though Offred later learns that her predecessor had committed suicide - a sure sign of the devastating effects of this ongoing experience of trauma on the characters in the novel - nevertheless these forbidden words offer the first signs of resistance in this situation of insidious trauma. As Kayla Chadwick poignantly reflects on the cinematic portrayal of this scene in her essay of the political relevance of the Handmaid's Tale in the current political climate, "The fact that her unknown predecessor risked so much to scratch out the sentiment in a society where she is forbidden to read and write is enough for June to take courage from the shapes of the letters alone." 56 In the novel, it is these words that instil in Offred a measure of hope and resolve to in the end escape her circumstances - presumably through the female version of the Underground Railroad. ${ }^{57}$

Third, these glimpses of resistance amidst the portrayal of insidious trauma are important as they reveal that the power structures that are causing the harm are not set in stone, but instead that they may "become vulnerable once their norms are questioned and lose power in the face of resistance." Vickroy describes Atwood's writing as follows:

Her novels present cracks in the silencing armour, as other characters in the protagonists' sphere challenge the coercive lies of the powerful and provide a sense of reality and hope, allowing the protagonists to slowly recover a sense of self and voice. ${ }^{58}$

This glimpses of resistance amidst the reality and the effects of insidious trauma also are important when reading biblical narratives. In the story of Rachel and Leah, the clearest sign of resistance, or in Vickroy's words, "the cracks in the silencing armour," is found in the narrative told in Gen 31 where the two sisters Leah and Rachel come together to trick their father who had refused to give the two daughters any part of their inheritance. The sisters' words about their father attest to the anger they felt about how he had treated them - further signs of the years of ongoing suffering they experienced at the hand of their father that included engineering their married life, which set into motion the

\footnotetext{
56 Chadwick," Don't Let the Bastards Grind You Down."

57 Kimberly Fairbrother Canton, "I'm Sorry My Story is in Fragments': Offred's Operatic Counter-Memory," English Studies in Canada 33/3 (2007): 125-144 (here 135).

58 Vickroy argues that often this resistance "is portrayed as an inner voice, working through trauma, and on the verge of being made public," "Voices of Survivors," 133.
} 
vigorous battle for the love of the same man. However, as Jacqueline Lapsley has compellingly shown in her essay on Gen 31, Rachel's words are doublevoiced in nature - "I cannot rise before you because the way of women are upon me" directed at her father speak of her menstruation cycle but also voice her inability to have access to a fair judicial process. Lapsley argues that "this type of discourse, [that] has served as a powerful form of protest to groups enslaved, dispossessed, or otherwise oppressed persons throughout history," 59 "constitutes a discourse of resistance, a subtle protest against the patriarchal discourse and social structures that attempt to silence her." ${ }^{\circ}$ Indeed, these "cracks in the silencing armour" can be said to serve as a powerful tool for instilling hope in readers from different times and places, while also strengthening their resolve to work for change.

Lastly, it is significant as well to observe those instances in trauma narratives where characters are shown not to face their trauma, or where their trauma is negated. For instance, in contrast to Offred in The Handmaid's Tale, it is telling that Bilhah and Zilpah, the two handmaid characters do not have bestowed on them a voice or shown to engage in any form of making sense of what must have been greatly traumatizing conditions. Vickroy writes that when characters in trauma narratives are unable to make sense of the traumatizing events in which they find themselves, it is up to the readers to do the work of critically reflecting on "the flawed thinking, feeling, and behaviour of the traumatized individual." 61 This is even more pressing with reference to the biblical handmaids, in which case, one finds a complete absence of any attempts to voice their pain. As Vickroy says it well:

Many fiction writers portray their traumatized characters in the midst of this dilemma as they perform their symptoms. However, the writers make connections for readers that victims cannot, or portray victims trying to fit the pieces together, with some partial success. They do not always offer readers answers, but allow the reader into that uncertain experience and try to reconnect characters' memories and emotions. ${ }^{62}$

Womanist scholars, according to Smith, have "not only give voice to the marginalized and oppressed through [their] prophetic hermeneutical endeavours," but also, where possible, have sought to "disrupt, interrupt, or create space for marginalized and oppressed women, non-scholars, black 'women more commonly,' to speak for themselves and others." 63 These efforts

59 Jacqueline E. Lapsley, Whispering the Word: Hearing Women's Stories in the Old Testament (Louisville, KY: Westminster John Knox 2005), 27.

60 Lapsley, Whispering the Word, 22.

${ }_{61}$ Vickroy, "Voices of Survivors," 138.

62 Vickroy, "Voices of Survivors," 140.

63 Smith, "This Little Light of Mine," 123. 
are vital if we were to draw connections on behalf of these two handmaids that is sensitive to the ways in which gender, race and class intersect with insidious trauma. In this regard, Wilda Gafney has led the way, poignantly reminding us of the deep-seated trauma Bilhah (and Zilpah) had endured:

Bilhah represents the woman who has had more than one abusive relationship, the woman who has been raped by more than one perpetrator, the woman who has been betrayed by women and men, the woman who has never known anyone to value her for more than what they think about her body, in part of the whole. And Bilhah represents the woman who survives her abuse. ${ }^{64}$

With the above proclamation, it is evident that the original handmaids' stories speak far beyond themselves. Gafney seeks to undo the erasure of these women by reminding us what Bilhah may have experienced, in addition to many other women like Bilhah, including what also June/Offred, the handmaid in Atwood's novel, definitely would have experienced. Gafney continues to defy the erasure of these women by calling them by name in a liturgical setting: "Mother Bilhah, womb-slave of Israel, we call your name." "Mother Zilpah, womb-slave of Israel, we call your name." 65 This designation at once remembers the insidious trauma experienced by these women whose bodies were enslaved, but also by saying their name, helps them to rise up and not to let the 'bastards' grind them down.

\section{F CONCLUSION}

This article has sought to read two interconnected trauma narratives through the lens of insidious trauma. As was argued in the previous section, this reading strategy offers distinct ethical implications that speak of trauma narratives' innate ability to effect change. As Janet Rumfelt, writes about the promise of narrative repair associated with stories that narrate trauma: "In telling their stories, victims no longer frozen in time; rather they are advocates, one who tell a story in the present about the past so as to create a better future."66

It is, however, not only the victims and survivors represented in the ancient and contemporary trauma narratives who may benefit from telling stories in order to challenge what is unjust, and restore what has been ruined. Also readers in other times and places reading such narrative accounts of insidious trauma may be empowered to recognize something of the truth of their own situations. In what Griselda Pollock calls an act of "trans-subjective

64 Gafney, Womanist Midrash, 69.

65 Gafney, Womanist Midrash, 70-71.

66 Janet L Rumfelt, "Reversing Fortune: War, Psychic Trauma, and the Promise of Narrative Repair," in Interpreting Exile: Displacement and Deportation in Biblical and Modern Contexts (ed. Brad E. Kelle, Frank R. Ames and Jacob L. Wright. Atlanta, GA: Society of Biblical Literature, 2011), 323-344 (here 339). 
borderlinking, one finds how readers from vastly different contexts may recognize in these trauma narratives the painful reality of the daily suffering endured by especially women and other marginalized entities in their own contexts. ${ }^{67}$ Actually, Margaret Atwood's novel can be said to be one attempt to give voice to the experience of the original handmaids, so not only honouring their suffering but also imagining signs of resistance amidst the descriptions of insidious trauma. It is evident in the great appeal of The Handmaid's Tale in today's context that contemporary readers are emboldened by the small instances of resistance amidst the overbearing descriptions of insidious trauma that signify the characters' refusal to succumb to the dystopian world imagined by its orchestrators. Today's readers of the contemporary trauma narrative by Margaret Atwood, inspired by its biblical counterpart from a time and place long ago, may hence do their utmost to bring to fruition what one of the signs during one of the Women's Marches in the United States so aptly implored: "Make The Handmaid's Tale fiction again."

\section{BIBLIOGRAPHY}

Alexander, Jeffrey. Trauma: A Social Theory. Cambridge: Polity Press, 2012.

Atwood, Margaret. The Handmaid's Tale. Toronto: McClelland \& Stewart, 1985.

Atwood, Margaret. "Margaret Atwood on What 'The Handmaid's Tale' Means in the Age of Trump," New York Times, 10 March, 2017.

Aymer, Margaret. "Outrageous, Audacious, Courageous, Willful: Reading the Enslaved Girl of Acts 12." In Gay L. Byron and Vanessa Lovelace (eds.). Womanist Interpretations of the Bible: Expanding the Discourse. Atlanta, GA: SBL. pp 265-290, 2016. https://doi .org/10.2307/j.ctt1h1htgx.16.

Becker, Eve-Marie, Dochhorn, Jan \& Holt, Else K. (eds.). Trauma and Traumatization in Individual and Collective Dimensions: Insights from Biblical Studies and Beyond. Göttingen: Vandenhoeck \& Ruprecht, 2014. https://doi.org/10.13109 19783666536168.

Boase, Elizabeth \& Frechette, Christopher G. (eds.). Bible through the Lens of Trauma. Semeia Studies 86; Atlanta, GA: SBL Press, 2016.

Bowen, Nancy. "Women, Violence, and the Bible." In Linda Day and Carolyn Pressler (eds.). Engaging the Bible in a Gendered World: An Introduction to Feminist Biblical Interpretation in Honor of Katharine Doob Sakenfeld. Louisville, KY: Westminster John Knox. 2006, pp 186-199.

Brown, Laura S. "Not Outside the Range: One Feminist Perspective on Psychic Trauma." In Cathy Caruth (ed.), Trauma: Explorations in Memory. Baltimore, MD: Johns Hopkins University Press. 1995, pp 100-112.

67 Griselda Pollock shows how artistic expressions facilitate a "virtual encounter" between the experiences of individuals or groups from long ago in a different time and place and what contemporary readers/viewers may experience on a conscious or subconscious level, “Art/Trauma/Representation," Parallax, 15:1 (2009): 40-54 (here 42). https://doi.org/10.1080/13534640802604372. 
Byron, Gay L. \& Lovelace, Vanessa. Womanist Interpretations of the Bible: Expanding the Discourse. Atlanta, GA: SBL, 2016. https://doi.org/10.2307/j.ctt1h1htgx.

Callaway, Alanna A. "Women Disunited: Margaret Atwood's The Handmaid's Tale as a Critique of Feminism," Master's Thesis. 3505. https://doi.org/10.31979/etd.yxm y-ds98.

Chadwick, Kayla. "Don't Let the Bastards Grind You Down: Nolite te bastardes carborundorum, Bitches." Huffington Post. Available at https://www.huffing tonpost.com/entry/dont-let-the-bastards-grind-you-down_us_59095e17e4b0527 9d 4edc109 [2018, 11 March].

Claassens, L Juliana. Claiming Her Dignity: Female Resistance in the Old Testament. Collegeville, MN: Liturgical Press, 2016.

Claassens, L Juliana. "Cultivating Compassion? Abigail's Story (1 Samuel 25) as Space for Teaching Concern for Others." In Frits de Lange, \& L Juliana Claassens (eds.), Considering Compassion: Global Ethics, Human Dignity, and the Compassionate God. Eugene, OR: Wipf \& Stock. 2018, pp 157-169.

Eyerman, Ron. "Social Theory and Trauma." Acta Sociologica 56/1 (2013): 41-53. https://doi.org/10.1177/0001699312461035.

Fairbrother Canton, Kimberly. 'I'm Sorry My Story is in Fragments: Offred's Operatic Counter-Memory." English Studies in Canada, 33/3(2007): 125-144. https://doi.org/10.1353/esc.0.0072.

Gafney, Wilda C. Womanist Midrash: A Reintroduction to the Women of the Torah and the Throne. Louisville, KY: Westminster John Knox, 2017.

Garber, David G. "Trauma and Biblical Studies." Currents in Biblical Research. 14/1 (2015): 24-44. https://doi.org/10.1177/1476993x14561176.

Guest, Deryn. "Hiding Behind the Naked Women in Lamentations: A Recriminative Response," BibInt 7/4(1999): 413-448. https://doi.org/10.1163/156851599x00308.

Harris-Penny, Melissa V. Sister Citizen: Shame, Stereotypes, and Black Women in America. New Haven, CT: Yale University Press, 2011.

Indu, B C. "Flowers of Survival: An Ecofeminist Reading of Margaret Atwood's The Handmaid's Tale." International Journal of Humanities and Social Science Invention. 2(4):7-9. Available at http://www.ijhssi.org/papers/v2(4)/version-2/B 240709.pdf [2018, 6 March], 2013.

Jackson, Melissa A. Comedy and Feminist Interpretation of the Hebrew Bible: A Subversive Collaboration. Oxford: Oxford University Press, 2012. https://doi.org 110.1093/acprof:oso/9780199656776.001.0001.

Jacobs, Mignon R. Gender, Power, and Persuasion: The Genesis Narratives and Contemporary Portraits. Grand Rapids, MI: Baker Academic, 2007.

Janzen, David. The Violent Gift: Trauma's Subversion of the Deuteronomistic History's Narrative. New York: Bloomsbury T\&T Clark, 2013.

Kalmanofsky, Amy. Dangerous Sisters of the Hebrew Bible. Minneapolis, MN: Fortress Press, 2014.

Kelle, Brad E. "Wartime Rhetoric: Prophetic Metaphorization of Cities as Female." In Brad E. Kelle and Frank R. Ames (eds.). Writing and Reading War: Rhetoric, Gender and Ethics in Biblical and Modern Contexts. Atlanta, GA: Society of Biblical Literature. 2008, pp. 95-112.

Koepf-Taylor, Laura W. Give Me Children or I Shall Die: Children and Communal Survival in Biblical Literature. Minneapolis, MN: Fortress, 2013. 
Kozlova, Ekaterina E. Maternal Grief in the Hebrew Bible. Oxford: Oxford University Press, 2017. https://doi.org/10.1093/oso/9780198796879.001.0001.

Lapsley, Jacqueline E. Whispering the Word: Hearing Women's Stories in the Old Testament. Louisville: Westminster John Knox, 2005.

Meyers, Carol. Rediscovering Eve: Ancient Israelite Women in Context. Oxford: Oxford University Press, 2013.

Moss, Candida R \& Baden, Joel S. Reconceiving Infertility: Biblical Perspectives on Procreation and Childlessness. Princeton, NJ: Princeton University Press, 2015.

Neuman, Shirley C. Just a Backlash: Margaret Atwood, Feminism, and The Handmaid's Tale University of Toronto Quarterly 75/3 (2006): 857-868. https://doi.org/10.3138/utq .75.3.857.

Olson, Dennis. "Revenge, Forgiveness, and Sibling Rivalry: A Theological Dialogue Between Scripture And Science." Ex Auditu. An International Journal of the Theological Interpretation of Scripture. pp 94-119, 2012.

Pollock, Griselda. "Art/Trauma/Representation," Parallax, 15:1 (2009) 40-54. https://doi.org/ 10.1080/13534640802604372.

Rambo, Shelly. Resurrecting Wounds: Living in the Afterlife of Trauma. Waco, TX: Baylor University Press, 2017.

Root, Maria P.P. "Reconstructing the Impact of Trauma on Personality." In Laura S Brown \& Mary Ballou (eds.), Personality and Psychopathology: Feminist Reappraisals. New York: The Guilford Press. 1992, pp 229-265.

Ross-Burstall, Joan. "Leah and Rachel: A Tale of Two Sisters," Word \& World 14/2: 1994, 162-170.

Rumfelt, Janet L. "Reversing Fortune: War, Psychic Trauma, and the Promise of Repair.” In Brad E Kelle, Frank R Ames, \& Jacob L Wright (eds.), Interpreting Exile: Displacement and Deportation in Biblical and Modern Contexts. Atlanta: Society of Biblical Literature. 2011, pp 323-344.

Scholz, Susanne. Sacred Witness: Rape in the Hebrew Bible. Minneapolis, MN: Fortress Press, 2010.

Smith, Mitzi J. "This Little Light of Mine: The Womanist Biblical Scholar as Prophetess, Iconoclast, and Activist," in Mitzi J. Smith (ed.). I Found God in Me: A Womanist Biblical Hermeneutics Reader. Eugene, OR: Cascade Books. 2015, pp 109-130.

Trible, Phyllis. Texts of Terror: Literary-Feminist Readings of Biblical Narratives. Philadelphia, PA: Fortress, 1984.

Vickroy, Laurie. "Voices of Survivors in Contemporary Fiction." In Michelle Balaev (ed.), Contemporary Approaches to Trauma Theory. London: Palgrave MacMillan. 2014, pp 130-151. https://doi.org/10.1057/9781137365941_6.

Washington, Harold C. "Violence and the Construction of Gender in the Hebrew Bible: A New Historicist Approach 1." BibInt 5: 324-363, 1997.

Williams, Delores S. Sisters in the Wilderness: The Challenge of Womanist God-Talk. Maryknoll, NY: Orbis. 1993.

L. Juliana Claassens, Professor of Old Testament, Head of Gender Unit, Faculty of Theology, Stellenbosch University Stellenbosch, South Africa. jclaassens@sun.ac.za. ORCID: https://orcid.org/0000-0002-5490-0974. 